\title{
Sabbhata Yatra
}

Jurnal Pariwisata dan Budaya

Volume 1 Nomor 2 Desember 2020

\section{PERCEIVED IMPACT OF CULTURAL TOURISM AMONG THE RESIDENTS: FOCUSING ON RUWATAN DREADLOCKS CHILDREN IN DIENG KULON VILLAGE}

\author{
Sahid $^{1}$, M. Elfan Kaukab ${ }^{2}$ \\ ${ }^{1}$ Faculty of Language and Literature, Universitas Sains Al-Qur`an, Wonosobo, Indonesia \\ ${ }^{2}$ Faculty of Economics and Business, Universitas Sains Al-Qur'an, Wonosobo, Indonesia \\ ${ }^{1}$ sahid.jpn123@gmail.com, ${ }^{2}$ elfan@unsiq.ac.id
}

\begin{abstract}
Dieng Kulon village is one of the villages which is located in Dieng Plateau Area, Banjarnegara regency. There is a tradition of ruwatan ritual procession that has been done by the residents since hundred years ago. The ruwatan then becomes the cultural tourism. This study aims at exploring the perceived impact of cultural tourism among the residents in Dieng Kulon village. Participant observation and in-depth interview are conducted to local residents in Dieng Kulon village and governmental officials who manage the tourism sector in the regency of Banjarnegara. The data is then comprehensively analyzed using descriptive qualitative method. The result of this study shows that based on the residents 'perception, the presence of dreadlocks children bring the "berkah" or prosperity. The dreadlocks children in Dieng have the distinct characteristics, they have to conduct the ritual procession of ruwatan hair cutting. Some residents agree for projecting the public ruwatan into cultural tourism on the reason of cultural preservation while others do not agree because they worry about the decrease of sacredness and cultural value of that tradition. The subsistence of them also gradually change into the tourism activity.
\end{abstract}

Key words: Perceptions, Residents, Cultural tourism, Ruwatan

\section{INTRODUCTION}

Dieng Kulon village is one of the villages which located in Dieng Plateau Area and it belongs to Banjarnegara regency of Central Java. The residents of Dieng Kulon are Javanese who still believe in Java animism and dynamism. They still conduct the traditional rituals that considered as a sacred place. DiengKulon village also has the variety of myths which still exist until now. In general, the residents in that village has a religion, that is Islam. And they are also dutiful Muslims. However, the muslim culture in that village is still influenced by the Javanese indigenous culture who follow the syncretism. By the time of modernization, the residents of Dieng Kulon village become a modern community but they still can not leave their traditional ways of life such as ruwatan.

The phenomena of "anak gembel" is one of the particular myth that still exist and become famous now. "Anak gembel" or children with dreadlocks are the 


\section{Sabbhata Yatra}

Jurnal Pariwisata dan Budaya

Volume 1 Nomor 2 Desember 2020

offspring of the ancestral founder of Dieng, Ki Ageng Kolodete. He left the message to the residents of Dieng Kulon to keep and take care the children with dreads. Because there is a supernatural being that "inhabit" and "maintain" these dreads. Dreadlocks children are originally born in normal. Then they got a fever and the dreads started to grow on their head (Damayanti 2011).

The procession of ruwatan must be conducted to the children with dreadlocks. They can not let the dreads grow until the children become adult. If they do that, there would be a disaster to the children or their family. The residents and the tourist are interested in the procession of ruwatan therefore it has been viewed as a potential cultural tourism. Visiting to the historical area or archaeological sites; participating in the community festivals; watching traditional dances or ceremonies; or merely shopping for handcrafts belong to the cultural tourism activities (Besculides, Lee, and McCormick 2002:303).

The indigenous people of Dieng has conducted the procession of ruwatan dreadlocks children since hundreds years ago and they regard that procession as a sacred ceremony; and gradually that ceremony is now changed into cultural tourism. The emergence of cultural tourism in Dieng Kulon village has led to the residents' perceptions and attitudes toward the impact of cultural tourism.Eysenck and Keane (Demuth 20013:31) described that

"Perception is the end product of the interaction between stimulus and internal hypotheses, expectations and knowledge of the observer, while motivation and emotions play an important role in this process. Perception is thus influenced by a wide range of individual factors that can lead to an inadequate interpretation."

In the perspective of tourism, perceptions is influenced by some factors such as social and economic factors; community attachment, length of residence in an area, and economic dependency on tourism. All of them can influence resident perceptions and attitudes toward tourism.

Depending on the destination studied and the factors investigated in each study, studies of residents' perception and attitudes toward the impact of tourism is very important of giving the sugggestion to the residents' view of the tourism as either positive(Murphy 1983; Perdue et al. 1987; Allen et al.1988; Ritchie1988) or negative (Pizam1978; Liu and Var1986; Gursoy et al. 2002). The residents who 


\section{Sabbhata Yatra}

Jurnal Pariwisata dan Budaya

Volume 1 Nomor 2 Desember 2020

are staying in the same geographical area does not mean that they necesssarily belong to the same community (Gursoy et al. 2002; William and Lawson 2001). The most involved of residents with tourist and take the advantage from it have the positive perceptions and attitudes (Ritchie and Inkari 2006).

\section{Cultural Tourism}

The concept of cultural tourism tends to be applied to trips, going to any cultural resources with initial motivation (Hughes 1995) while Silberberg (1995) said that cultural tourism means visit by person from outside of the host community with full of certain motivations or in a part certain motivation like interested in historical, artistic, scientific or lifestyle/heritage offerings of a community, a region, group or institution.On the other hand, Tighe (1985) said that the cultural tourism in the broadest sense is all movements of person which might be included in the definition because they satisfy the human need for diversity, tending to raise the cultural level of the individual and giving rise to new knowledge, experience and encounter. From the various kinds of the definition of cultural tourism, then we define Cultural tourism as visiting historic or archaeological sites, being involved in community festivals, watching traditional dances or ceremonies and watching lifestyle/heritage offerings of a community.

\section{Perception and Attitudes}

Since the 1970s, residents' attitudes and perceptions toward tourism impacts on their community have been broadly analyzed by managers of the tourism industry, policy makers and academicians (Andereck et al. 2005; Andereck and Vogt 2000; Jurowski et al. 1997; Lankford 1994; Perdue et al. 1987; Doxey 1975; Young 1973). In the process of perception, individuals are required to provide an assessment of an object which can be either positive or negative; happy or not happy; and so on. The perception of it will form an attitude; which is a stable tendency to behave or act in a certain way and in certain situations as well (Polak 1976). Perception is defined as someone's process giving impression, assessment, opinion, feeling and interpreting something pursuant to presented information of other source. Through perception, we learn to recognize the world around us; that is a whole world which consists of objects 


\section{Sabbhata Yatra}

Jurnal Pariwisata dan Budaya

Volume 1 Nomor 2 Desember 2020

and also human being with all its occurrences (Meider 1958).

The literature review suggests that each tourism impact category includes positive and negative effects and, sometimes, residents' perceptions are contradictory. The economic tourism impact is mainly perceived by residents, on the positive hand, as a mean to improve local and state tax revenues, additional income, and economic quality of life (Huh and Vogt 2008; Haralambopoulos and Pizam 1996). Conversely, on the negative hand, residents seem to perceive an increase in the cost of living (Andriotis 2005; Andereck and Vogt 2000; Haralambopoulos and Pizam 1996; Liu and Var 1986).

\section{Ruwatan}

There are three kinds of ruwatan as mentioned in Sunarti's notes (Fajrin 2009:25):

The first is ruwatan sukerta; a ruwatan for children who are born as children who belonged sukerta. Basically, this is a ruwatan that requests for that the child's salvation and happiness in the future. The second is ruwatan sengkala; a ruwatan for people who experince obstacles in fortune, career and partner. Then the third is ruwatan lembaga (institutions) /agency; a ruwatan for the success of an

$\begin{array}{lcc}\text { institution } & \text { or } & \text { business } \\ \text { organizations } & \text { and } & \text { ruwatan } \\ \text { villages. } & & \end{array}$

There would be a serious problem if the people who belong to the category of sukerta do not take the ritual process of ruwatan. Javanese believe that there are spirit who maintain and inhabit the body of the certain people. The spirit control the owner of the body as always. Therefore the ruwatan is obeyed for them to avoid from the unexpected problem caused by the spirit. In Dieng Kulon Village the dreadlocks children belongs to the sukerta type that must take the ritual procession of ruwatan. Sukerta is derived from the word suker which means "dirty/sinful". The people with sukerta are sinful and full of bad luck. The negative supernatural threat has to be removed. Unless it is removed, it will negatively affect his/her life. This also implies that any business that a person involves will result in disadvantages or (loss). Sukerta has to be mentally cleaned through the ritual ceremony of ruwatan sukerta.

The Process of Cultural Tourism Development

The Dreadlocks Children (Anak Gembel) 
The Central Bureau of Statistics (2014) recorded a total population of children in Dieng Kulon Village, 768 with 47 children below 12 months, 280 children who age from 1 to 5 years old, and 441 children who are 6 to 13 years old. The researcher found that there are 4 dreadlocks children in Dieng Kulon Village (2015). So, the percentage of the population of dreadlocks children is 0.52 percent.

The researcher are difficult to find the dreadlocks children because sometimes there are some parents who hide their dreadlocks children. The parents do not want their children being exposed in social media and they also said that their children are not the object that can be touched and watched freely by everyone. On the other hand, there are some parents who intentionally want their dreadlocks children being exposed, they said that having them (dreadlocks children) is the blessing from the God.

Kyai Kolodete is believed as the ancestral founder of Dieng Plateau Area and a male dreadlocks children is the offspring of him while a female dreadlocks children is believed as the offspring of Nini Roro Ronce. The residents of Dieng Kulon Village convince that the prosperity of their village is marked by the presence of dreadlocks children.

The dreadlocks children has unique characters and they tend to be naughty, fussy and hyper active. The dreads start to grow at any ages such as from 5 months, 6 months, one year or two years. Before the dreads start to grow, it's characterized by fever on high temperature then the body back to normal again after the dreads growing. Normally, they will ask for ritual procession of hair cutting (ruwatan) before nine years and they will ask something before procession. The demand must be granted or the dreads will grow again if the parents do not fulfill their demand. Their hair also can not be cut any time. The time depends upon the children's request. If the dreads are cut forcibly, the children will get sick and the dreads will grow again. During the ritual procession of ruwatan, all the requirements must be completed.

The various perceptions emerge regarding the growth of the dreads of the children in Dieng Plateau Area. First, these children are seen to be the descendants of the ancestral founder of Dieng (Kyai Kolodete and Nini Roro Ronce). Secondly, it is seen as an environmental factor. Finally, the dreads 


\section{Sabbhata Yatra}

Jurnal Pariwisata dan Budaya

Volume 1 Nomor 2 Desember 2020

are seen as heredited from their parents. Suratsih (2009) conducts the study to the family who are experienced dreadlocks. The result of the study mentions that the dreadlocks happen because of the genetic problem.

The Emergence of Ruwatan as Cultural Tourism

Ruwatan sukerta, sengkala and ruwatan lembaga are the basic ruwatan that often conduct in Java and in Dieng Plateau Area the ruwatan of dreadlocks children belong to the ruwatan sukerta. From hundred years ago, the residents of Dieng Plateau Area conducted the ruwatan privately, it means that the ruwatan ritual procession held by the parents of dreadlocks children and witnessed by the relatives of them. There is only one dreadlocks child who involves in the private ruwatan and this ritual is guided by the traditional leader of that village. All the fund of ruwatan is provided by their parents.

Dieng Kulon that is one of the villages located in Dieng Plateau Area also conducted the private ruwatan of dreadlocks children. There is much fund for conducting the ritual process of ruwatan. The parents of dreadlocks children must save the money early, started from their son/daughter getting the dreads on their head.

Due to the economic condition of the residents in Dieng Kulon village that not all the parents of dreadlocks children are easy to get the fund for ritual procession makes the youth of Dieng Kulon village start to think how can they help for them to support the financial problem of conducting the ruwatan. Then in 2010, initiated by Pokdarwis Dieng Pandawa and helped by the youth of Dieng Plateau Area, the public ruwatan is created. Public ruwatan which is the core event in DCF (Dieng Culture Festival) is the large scale of ruwatan and it involves more than one dreadlocks children. The fund of this public ruwatan is supported by the sponsor and government so that the parents of dreadlocks children do not need to provide the much cost for ritual procession of ruwatan and also to fulfill the demand of dreadlocks children.

Pokdarwis is an institutional in the community whose members consist of tourism actors who are responsible for the growth and development of tourism as well as the realization of Sapta Pesona (safe, orderly, clean, cool, lovely, warmhearted, memories) in promoting the regional development through tourism, and use it for the welfare of the 


\section{Sabbhata Yatra}

Jurnal Pariwisata dan Budaya

Volume 1 Nomor 2 Desember 2020

surrounding community (Ministry of Tourism and Creative Economy 2012). Pokdarwis Dieng Pandawawas the first Pokdarwis that is found in Dieng Plateau Area (the area of Banjarnegara and Wonosobo regency) and it empowers the youth and the society of Dieng Kulon village and it serves as a model of empowerment among other Pokdarwis in Dieng Plateau Area.

Public ruwatan that is held annually from 2010 in Dieng Kulon village appreciated by all stake holders (traditional leader, residents and government) and also the tourists from any region. They are really interested in the procession of ruwatan dreadlocks children. Gradually the sacred of public ruwatan goes to cultural tourism.

\section{RESEARCH METHOD}

In-depth interview has been done by the researcher with some of the stakeholders namely residents, dreadlocks children's parents, sesepuh (traditional leader), the Pokdarwis Dieng Pandawa, village chief, local government (Department of Culture and Tourism in Banjarnegara Regency), local businesses (homestay, hotels, stores, food stall owners and street vendors) and tourists (foreign and domestic). The researcher also becomes the participant observation to obtain deeper understanding of the situation and the researcher also do not forget to make a documentation uses IC recorder and digital camera to acquire the authentic evidence through the permission from the informants.

Data triangulation, methodological triangulation and time triangulation also used to get the validity of the data. Then the researcher starts to analyze the data collection by conducting the data reduction at the first, it is because the more the researcher often goes to the field, the more complicated the data that the researcher gets. The next, data reduction is analyzed to get a conclusion by drawing/verifying.

\section{DISCUSSION}

Residents` Perception on the Importance of Dreadlocks Children in their Community

The characters of dreadlocks children are very unique, they are little bit different from the character of normal children (children without dreads). Dreadlocks children tend to be naughty, fussy and hyperactive. All the demand of dreadlocks children must be granted 


\section{Sabbhata Yatra}

Jurnal Pariwisata dan Budaya

Volume 1 Nomor 2 Desember 2020

unless they will get fever and sometimes their crying do not stop, that is why the parents of them try to earn much money to treat them well. The residents understand that the dreadlocks children behave as such because there is a spirit who inhabit and controls the characters of them. Residents who live around the dreadlocks children really understand with the condition of them. They know that dreadlocks children could not be asked nor be denied because it is gift from the God and all the residents have the possibility to have them. The residents of Dieng Kulon village know that it is not easy to keep and treat them. They also understand what should they do to get the "berkah". If the residents have something that is asked by them, they must give it to them. Residents believe that it is the spirit actually who possess and control the dreadlocks children that ask something.

Most of the residents in Dieng Kulon village regard that the presence of dreadlocks children bring "berkah" (mystically beneficent blessings) to their life because dreadlocks children are the descendant of the ancestral founder of Dieng Plateau Area namely Kyai Kolodete who gives the message to the residents to keep and cure the dreadlocks children.

The residents perceive that dreadlocks children are very important in their community. They feel that the existence of the dreadlocks children in Dieng Kulon village bring them to the prosperity if the residents keep and care them well. But the dreadlocks children also can bring them to the bad luck if the residents ignore them.

\section{Residents' Perception toward the Projecting of Public Ruwatan into Cultural Tourism}

Believing in myth that still exist in Dieng Kulon village makes the residents still uphold the spiritual culture. They know that the disaster that threaten their life are the results of imbalance between the natural life and supernatural life. This imbalance would lead to a disaster that needs to be held ritually.

In Dieng Kulon village, the family that have a dreadlocks kid must conduct the ritual procession of ruwatan. The family have to prepare all the needs of ruwatan. They will invite the relatives to be witness during the ritual procession held and the procession is guided by the sesepuh (traditional leader). The demand of the dreadlocks kid also must be prepared before the procession of hair 


\section{Sabbhata Yatra}

Jurnal Pariwisata dan Budaya

Volume 1 Nomor 2 Desember 2020

cutting. They have to be sure that all the requirements of the ruwatan ritual procession of hair cutting are completed. One of the requirements only is not fulfilled the ritual will be failed and the dreads of the dreadlocks children will grow again and they will get sickness/fever.

The ruwatan that is held by each family that has dreadlocks children can be called as private ruwatan and it involves only one dreadlocks kid. The private ruwatan had been done by the residents of Dieng Kulon village from hundreds years ago and it needs a big fund covered by the family. The family of dreadlocks children must save the money since they know that their son/daughter grow the dreads. Because not all the dreadlocks children's parents are rich enough to cover the fund of ritual procession.

Public ruwatan then emerge in Dieng Kulon village (the core of event in Dieng Culture Festival). The aim of public ruwatan for the first time is to help the dreadlocks children's parents to conduct the ruwatan ritual procession of hair cutting. In public ruwatan, the parents of dreadlocks children do not need to prepare anything because all the requirements of ruwatan are covered by the committee.

There are more than one dreadlocks children who join in public ruwatan.In the public ruwatan, the time of ritual procession has been scheduled by the committee. The dreadlocks children that join are the children who want to cut their hair at that time.

Various perception emerges among the residents of Dieng Kulon village toward the public ruwatan. Ruwatan is a sacred ritual procession but when it goes to public and tourists visit that ceremony, the purpose of conducting the ruwatan might be changed, it's now not just only for a ritual purposes but more of as cultural tourism. Some of the resident who are living in Dieng Kulon village and feel the benefit of that cultural tourism agree when the public ruwatan projects into cultural tourism. They said that the purity and the sacredness of the ruwatan ritual procession is still keeping and the public ruwatan of dreadlocks children does not change the content of the tradition. On the other hand, residents who are really concern toward the tradition of ruwatan feeling hard in projecting the public ruwatan into cultural tourism even though the committee said that it's only cultural 


\section{Sabbhata Yatra}

Jurnal Pariwisata dan Budaya

Volume 1 Nomor 2 Desember 2020

preservation purposes, help the parents of dreadlocks children to conduct the ritual procession of ruwatan and let the tradition is known by all over the world.

Some of the residents perceive that the changing of cultural value happen when the tradition is utilized as cultural tourism. The residents who agree of projecting the public ruwatan into cultural tourism do not really think of the purity of the tradition again or the sacredness of the tradition but how many tourists can come to that event become more important to them. Sometimes several ways are done to make the tourists more interested and one of them is by changing the content of the tradition.

\section{The Impact of Cultural Tourism} toward the Residents`Subsistence

Dieng Kulon village which is located in Banjarnegara regency is a part of Dieng Plateau Area. Located at an altitude around 2093 meters above sea level makes the temperature of that places cold-15 to 20 degrees C. Dieng Kulon village is approximately $70 \mathrm{~km}$ to the north of Banjarnegara. The area can be reached by private vehicles and public transportation because it is located in the tourism area of Wonosobo and Banjarnegara Regency. From Banjarnegara, the area can be reached in about 1 hour and 30 minutes using a private vehicle at a speed of $60 \mathrm{~km} / \mathrm{h}$. When using a public transportation, it can be reachedmore than 2 hours.

The total area of the village of Dieng Kulon is 337.846 ha and agricultural fields covering an area of 96.15 ha $(28 \%)$ that's very good for planting the vegetables. Cabbage, potato and chili are the agriculture product that produced by the farmer of Dieng Kulon. Because of the educational background and the condition of area, most of the residents in Dieng Kulon village choose to be a farmer. Central Bureau of Statistics (2014) said that from the total population of $3.513 ; 1.899$ people finish their study until the elementary school only. People who only get the low education have no reason to refuse the farmer as their subsistence. Every morning they go to the mountainous garden and go back to their home before 12 o'clock because at that time the weather is very hot and they also have to pray Dzuhur (moslem prayer) and return to the field again to finish their work until 3 p.m.

The residents do the farming not in their own land at sometimes. They work for their neighbors who have large land and they will get Rp. 35.000 to Rp. 


\section{Sabbhata Yatra}

Jurnal Pariwisata dan Budaya

Volume 1 Nomor 2 Desember 2020

45.000 for women worker and Rp. 50.000 to Rp. 70.000 for men perday. It seems that the income is high for the people in the village but they should remember that they can not get that kind of income everyday because the owner of the land/field use the worker only in the certain season. And they also have to work hard from 7 a.m. to 3 p.m. The kinds of work for ordinary people are planting the vegetables, harvesting and treating the plants.

Many tourism objects in Dieng Plateau Area can not make the residents of Dieng Kulon village much interested in the tourism activity. The profession of being tour guide also still hold by the people from the outside of Dieng Plateau Area. The residents often see the tour guides from any regions who lead the tourist either from domestic or foreign but the residents can not join on that activity because they do not have any enough skill of tourism.

After the emergence of public ruwatan (the main event in Dieng Culture Festival), the residents of Dieng Kulon village begin to change the way of their thinking toward the tourism. They start to have interested in the activity of tourism. Then the Department of Culture and Tourism, Banjarnegara and the youth of
Dieng Kulon village; they discuss about how to develop the tourism in their area.

Now we can see that there are some tourism activities which is done by the residents in Dieng Kulon village. Street vendors are there in almost any tourist resorts, they said that they can do this job easily and the income also can support their daily needs. Being clown also done by the residents in the area of Arjuna Temple. The tourists who wants to take a photo with the clown should pay around Rp. 5.000- Rp. 10.000. There are also some horses that can be rent by the tourists to go around the tourism object.

Home industry in Dieng Kulon village is also there. The residents produce the potato crispy, mushroom crispy and carica sweet. The very special in Dieng is carica sweet, the fruit is like papaya and it grows only in Dieng Plateau Area. One cup of carica sweet can be purchased by Rp. 5000- Rp. 10.000. The residents who are good at capital, they open the store to sell the special food/snack from Dieng and the souvenirs. Stores, kiosks and grocery shop are currently lined up along the road in the village of Dieng Kulon which reached the number of 137 . There are also at least 5 food stalls there. 


\section{Sabbhata Yatra}

Jurnal Pariwisata dan Budaya

Volume 1 Nomor 2 Desember 2020

The tourist do not need worry if they want to spend the night in Dieng Kulon village. There are around 45 homestays and 1 hotel. The price per night in homestay is Rp. 150.000 to $\mathrm{Rp}$. 200.000 or it depends on the facilities which provided them. The tourist also can enjoy the taxy motor when they want to go to tourism object.

Many tourist who visit to Dieng make some residents of Dieng Kulon try to become the tour guide for domestic and foreign tourist. The emergence of cultural tourism in Dieng Kulon village make the tourists know much better what are there in Dieng. So that the tourists who visit to Dieng increase more significant and it makes the residents of Dieng Kulon village give the better service to them.

\section{CONCLUSION}

The residents in Dieng Kulon village regard that the presence of dreadlocks children bring the "berkah" or prosperity. The residents must keep and care them. The ignorance of residents toward the dreadlocks children will bring them to the disaster or bad luck. The dreadlocks children in Dieng have the distinct characteristics, they have to conduct the ritual procession of ruwatan hair cutting, if not they will bring the disaster or bad luck to their family.

Ruwatan that is done by the residents from hundred years ago now become the public ruwatan that involves more than one dreadlocks children and it's potential to be cultural tourism. Some residents agree for projecting the public ruwatan into cultural tourism on the reason of cultural preservation while others do not agree because they worry about the decrease of sacredness and cultural value of that tradition. It is not argued that the emergence of cultural tourism in Dieng Kulon village bring the impact toward the residents`subsistence. The subsistence of them gradually change into the tourism activity.

\section{BIBLIOGRAPHY}

Ap, J. 1992 Residents' Perceptions of Tourism Impacts. Annals of Tourism Research 19:665-690.

Bachleitner and Zins, A. 1999 Cultural Tourism in Rural Communities : The Resident's Perspective. Journal of Business Research44, 199-209.

Besculides, Antonia, Lee, Martha E. and McCormick, Peter J. 2002 Resident's Perception of the Cultural Benefits of Tourism. Annals Tourism Research 29(2)303-319.

Damayanti, P.A. 2011 Dinamika Perilaku "Nakal" Anak Berambut Gimbal di Dataran Tinggi Dieng. Lembaga 


\section{Sabbhata Yatra}

Jurnal Pariwisata dan Budaya

Volume 1 Nomor 2 Desember 2020

Penelitian Pengembangan

Psikologidan Keislaman (LP3K)

8(2)165-190.

Demuth, A. 2013 Perception Theories. Tranava: Tranava University.

Gursoy, D., C. Jurowski, and M. Uysal 2002 Resident Attitudes: A Structural Modeling Approach. Annals of Tourism Research 29:79105.

Gursoy, D., Kim, K. and Uysal, M. 2004Perceived Impacts of Festival and Special Events by Organizers: An Extension and Validation. Tourism Management25(...):171-181.

Grosspietch, M. 2006 Perceived and Projected Image of Rwanda: visitor and international tour operator perspectives. Tourism Management $27(\ldots): 225-234$.

Hoijer, B. 2011 Social Representations Theory a New Theory for Media Research-32(2):3-16.

Ritchie, B. W. and Inkari, M. 2006 Host Community Attitudes toward Tourism and Cultural Tourism Development: the Case of the Lewes District, Southern England. International Journal of Tourism Research 8:27-44.

Suratsih, at. Al. 2009 Pengembangan Modul Pembelajaran Genetika Berbasis Fenomena Lokal. Cakrawala Pendidikan Jurnal Ilmiah Pendidikan 2(..):165-176. 